Paideusis

\title{
Andragogical Epistemology and the Lacanian Discourse of the Hysteric: Learning Through Trauma, Trauma Through Learning
}

\section{Michael D. Berry}

Volume 17, Number 2, 2008

URI: https://id.erudit.org/iderudit/1072426ar

DOI: https://doi.org/10.7202/1072426ar

See table of contents

Publisher(s)

Canadian Philosophy of Education Society

ISSN

0838-4517 (print)

1916-0348 (digital)

Explore this journal

Cite this article

Berry, M. (2008). Andragogical Epistemology and the Lacanian Discourse of the Hysteric: Learning Through Trauma, Trauma Through Learning. Paideusis,

17(2), 3-16. https://doi.org/10.7202/1072426ar

\section{Article abstract}

Harm, this paper proposes, is a viable teaching objective. Presenting an andragogy of post secondary liberal arts education, this paper explores the relationship between critical thinking and subjective harm, arguing that subjective harm is an inevitable outcome of critical thinking practice. The author situates this teaching methodology within the discourse theory of psychoanalyst Jacques Lacan, positioning this critical thinking andragogy specifically within the Discourse of the Hysteric, which interrogates the institutionalized epistemology present in universities. Defining critical thinking as a subjective cognitive technique adjoined to reflexivity and reflective practice, this paper examines and refutes the university principle of primum non nocere (do no harm), arguing that it represents a logical incoherence in university principles. Semantically and conceptually examining the terminologies involved, the author contends that, to the extent that we accept the definition of "harm" found in the Discourse of the University, any teaching practice that valorizes critical thinking inevitably will, and should, be harmful.
This document is protected by copyright law. Use of the services of Erudit (including reproduction) is subject to its terms and conditions, which can be viewed online.

https://apropos.erudit.org/en/users/policy-on-use/ 


\title{
Andragogical Epistemology and the Lacanian Discourse of the Hysteric: Learning Through Trauma, Trauma Through Learning
}

\author{
MICHAEL D. BERRY \\ University of Alberta, Canada
}

\begin{abstract}
Harm, this paper proposes, is a viable teaching objective. Presenting an andragogy of post secondary liberal arts education, this paper explores the relationship between critical thinking and subjective harm, arguing that subjective harm is an inevitable outcome of critical thinking practice. The author situates this teaching methodology within the discourse theory of psychoanalyst Jacques Lacan, positioning this critical thinking andragogy specifically within the Discourse of the Hysteric, which interrogates the institutionalized epistemology present in universities. Defining critical thinking as a subjective cognitive technique adjoined to reflexivity and reflective practice, this paper examines and refutes the university principle of primum non nocere (do no harm), arguing that it represents a logical incoherence in university principles. Semantically and conceptually examining the terminologies involved, the author contends that, to the extent that we accept the definition of "barm" found in the Discourse of the University, any teaching practice that valorizes critical thinking inevitably will, and should, be harmful.
\end{abstract}

\section{Introduction}

The socially reproductive function of institutional education is well established (Hirst \& White, 1998). Particularly insofar as schools operate in loco parentis, they are charged with the responsibility of socializing students, culturally conditioning them so that they may participate as functional citizens within a pre-existing social system. The basic insight of pedagogical sociology is that schools operate as systems of social reproduction; "in sum," as Émile Durkheim wrote, "education, far from having as its unique or principal object the individual and his interests, is above all the means by which society perpetually recreates the conditions of its very existence" (1932/1956,p. 79). This process of perpetuation has significant epistemological implications. The very conditions of knowledge, even its structure and content, in a Foucaultian sense, are dictated by institutional power, and a principal postmodern insight is that subjectivity itself is conditioned by the mechanisms of institutional education (Foucault, 1980). The conditions of our knowledge-how we know, what we know, and even who we are (in light of this knowledge)—are powerfully shaped by the curricula and processes of our school lives.

(C) Copyright 2008. The author, Michael D. Berry, assigns to Paideusis the right of first publication and educational and non-profit institutions a non-exclusive license to use this document for personal use and in courses of instruction provided that the article is used in full and this copyright statement is reproduced. Any other usage is probibited without the express permission of the author. 
In this paper, I draw a heuristic distinction between pedagogy, as the art and science of teaching children, and andragogy, as the methodology of teaching adults. ${ }^{1}$ Especially with respect to the curricular values of self-reflectivity and critical thinking that comprise the foci of this piece, I intentionally, exclusively examine post secondary-particularly liberal arts-education. According to the socialization model of education, schooling is intended to instill common values, norms and social texts (Durkheim, 1932, p. 82). Social obedience and respect for rules and authority are essential amongst the social codes imparted in education. ${ }^{2}$ Yet, how do these mandates of social reproduction, and the attendant epistemological restraints imposed on education, coincide or conflict with an educational commitment to critical and reflective thought? How can critical educators negotiate a context of politicized professional directives to abide by the curriculum and teach "harmlessly"? Drawing on Megan Boler's work on "the pedagogy of discomfort" (1999), and Kevin Kumashiro's work on the "pedagogy of crisis" (2002), I deploy Lacanian theory in examining the process of critical thinking. I contend that discomfort, in Boler's terms, crisis, in Kumashiro's conceptualization, and even "harm," according to my own Lacan-inspired semantic configuration, are inevitable and desirable outcomes of critical andragogy.

Our objective, as critical post secondary educators, is to help students re-evaluate, interrogatively understand and integrate curricular (and perhaps extracurricular) lessons in a context of, ideally, autonomous agency. As Danny Weil writes, this involves a practice of "learning to reason dialectically... [by] distinguishing judgment from opinion," by recognizing and questioning subjective perspectives, and then positively, thoughtfully and self-consciously developing our own viewpoints and philosophies (2000, p. 3 \& passim). While the notion of secure, definite choices made on the basis of critical thought (as opposed to ongoing personal and philosophical uncertainty) is surely idealistic, critical thinking via open, dialectical reasoning is an unassailable value for teachers and educational practitioners. Herein, we are called upon to "practice what we preach," employing, in our teaching practices, the same self-reflective, critical processes that we strive to help instill in our students. It is precarious. In compelling our students to think critically about the world around them, we are inviting them to critically interrogate us, their teachers, and our role of authority. Moreover, we are encouraging them to introspect, to look courageously inwards. As in Boler's "pedagogy of discomfort," the critical andragogy I advocate "begins by inviting educators and students to engage in a critical inquiry regarding values and cherished beliefs, and to examine constructed self-images in relation to how one has learned to perceive others" (1999, p. 176). What they see within themselves and in the world is often discomforting, an affront to their sense of security. This discomfort involves an ethical and personal crisis, as Kumashiro's pedagogy of crisis contends, since, "learning that the very ways in which we think and do things is not only partial but oppressive involves troubling or 'unlearning' what we have already learned, and this can be quite an emotionally discomforting process, a form of "crisis"' (Kumashiro, 2002, p. 63,

\footnotetext{
${ }^{1}$ The term andragogy, must be treated circumspectly, with an awareness of its etymological masculinist bias. Andragogy derives from the root term "aner," which refers exclusively to adult males; this word, therefore, is imperfect in designating teaching practices intended for all adult learners within a specific setting, irrespective of gender. Despite this imperfection, the term is used, provisionally, throughout this paper, in accordance with its common current usage in designating adult learning, as opposed to children's learning (Gehring, 2000). This semantic difficulty highlights the need for critical reflection in education and educational theory, and the need to critically problematize language.

${ }^{2}$ Although Durkheim emphasizes this socially reproductive function in the context of early education, this sociological model is not intended to deny that critical thinking is increasingly valued in high school and elementary curricula; in fact, it is apparent that many educators and educational theorists have been working for decades to promote deep, meaningful critical engagement amongst students, even at the earliest stages of education (Weil, 2000). These important reforms are beyond the purview of this paper; herein, I focus on the role that critical thinking and self-reflective awareness play as andragogical values at the post secondary level, particularly in liberal arts curricula.
} 
emphasis in original). Evidently, the honest realizations attained through critical reflection can be difficult, uncomfortable and even, as I will argue, traumatic.

Yet, a perilously contradictory ethos has seemingly emerged in contemporary universities, challenging the tenet of genuine critical thinking. An ostensibly fundamental ethological premise-that teachers must "do no harm" to students-seems to obtain in Western universities; in fact, this appears as a nearly taken-for-granted assumption in our education system. There appears to be a pervasive presumption that all sanctionable pedagogy must be innocuous, a principle which seems to take the concept of "harm" as self-evidently meaningful (and, hence, presuming it to require no further explanation). Understood from a certain critical perspective, which avows the merits of discomfort, personal crisis, and even a certain form of subjective trauma, this harmlessness is both impossible and undesirable.

I argue that harm—understood and defined explicitly, critically and circumspectly-is not only desirable, but essential for meaningful liberal arts and humanities andragogy. The type of traumatic harm advocated here is particular to the student-as-subject, as understood in Lacanian psychoanalytic theory. Discomfort, in Boler's sense, and crisis, in Kumashiro's understanding, are essential components of this subjective trauma. The harm envisioned, however, must be approached carefully (since license to engage in "harmful" pedagogical practices must not be taken lightly, or approached haphazardly). This specific type of desirable, subjective harm, it is proposed, is a vital outcome of critical thinking and reflective practice. Framing university dialogue and structure according to the discourse theory of psychoanalyst Jacques Lacan, I contend that critical praxis is best situated within the "discourse of the hysteric" a framework that constantly challenges and unfixes power, knowledge and authority. Defining critical thinking as a taught value, essential for both "teacher" and "student," the paper argues that reflective practice is necessary to ensure that teachers embody the critical thinking they encourage, and execute their curricular objectives in a responsible, effective, and self-aware manner. The apparent university rhetoric of harm-avoidance, I argue, is intrinsically meaningless, authoritarian, and counterproductive to critical thinking, serving to oppose dissent and challenge from within. Ultimately, critical andragogy is psychologically, subjectively traumatic, and, to the extent that trauma is conflated with harm, critical teaching is inherently harmful. This harmfulness, however, is fundamentally constructive, in the service of genuine learning through critical and reflective skill development.

\section{University versus Teaching: The Discourse of the Master and the Discourse of the Hysteric}

When rendered intelligibly, the psychoanalytic theory of Jacques Lacan is useful in contextualizing university discourse. Lacan presented four discursive archetypes: the Discourse of the Master, the Discourse of the University, the Discourse of the Hysteric ${ }^{3}$, and the Discourse of the Analyst (Lacan, 1988, p. 16-17). The Discourse of the Master, the Discourse of the University, and the Discourse of

\footnotetext{
${ }^{3}$ Although scholars like Fink (1995), have offered defensive apologetics of the perceived sexist bias of Lacanian psychoanalytic terms (especially Lacan's deployment of the phallic signifier as the pivotal point of signification and meaning), it is necessary to problematize the gender implications of psychoanalysis' more contentious terminology. In particular, the sexist history of the term "hysteria" must be noted. As is well-known, hysteria was used in traditional Freudian psychoanalysis (and in much of the psychotherapy du jour in Freud's era) as a nearly catch-all category for various conditions attributed to extreme feminine neurosis. Arguably, virtually all women were perceived as psychologically and emotionally fragile, latent hysterics. This legacy denotes a profoundly sexist trend, identified by Moore as an integral part of psychoanalysis at an institutional level (2001). Although I advocate the utility of Lacan's "Discourse of the Hysteric" as a conceptual device in understanding critical pedagogy, I do not endorse the sexist connotations of the term 'hysteric,' or the identifiable sexist overtones of (some streams of) psychoanalysis in general.
} 
the Hysteric are most relevant to our educational considerations. Each discourse embodies a specific, differentiable relationship to power, truth, and knowledge production. In exploring these paradigms, we must recall that Lacan centralizes the issue of subjectivity, subjectivization being the means by which individuals are cognitively defined in and through discursive relationships with the world around them. This focus is particularly important for our andragogical philosophy, since the issue of subjective, cognitive definition is a central aspect of critical thinking and reflective practice.

The Master Discourse (rather than the University Discourse, ironically) reflects the contemporary university as a bureaucratic, authoritarian mechanism. A sort of primus inter pares, the Master Discourse is the precedent discourse; it is the means by which a physical individual becomes a subject, properly speaking, by becoming integrated into signification ${ }^{4}$ (mental comprehension through symbolization, in particular, language). Particularly important to institutional education is another component of the master discourse-its ideological function. The speaker, within this paradigm, embodies the role of the "master signifier," an inherently hollow and meaningless ideational construct that nonetheless has tremendous importance insofar as it is the fictive mental embodiment of a signified thing. More importantly, the "master signifier" is pivotal, as it is the fixed point on which all other signifiers rely. It can, therefore, be understood as the authoritative originary point for a cognitive schema. It is, in essence, a central premise.

In educational terms, the master signifier is the empty, self-reliant declaration of authority-an authority sustained only on the basis of having posited itself as authority. The master's power depends solely on its own initial self-declaration. Institutionally, this can be envisioned as the university's authority, based on the constitutional declaration in which its authority consists (reified in a constitution, or founding statement). ${ }^{6}$ The teacher, in this schema, embodies the master signifier, occupying the symbolic position of master and thereby possessing a fundamental authority. Here, the teacher wields a powerful seductive and coercive force; the teacher is enabled to define knowledge (Bracher, 1999; Parker, 2001). Yet, reduced to its logical foundations, the Master Discourse reveals its inherent arbitrariness: it is erected on the founding iterative act of a Master whose authority is inessential and ascribed. The Master discourse, "rests on an unfounded hypothesis, assertion or axiom, a special sentence the value of which neither can nor needs to be contested because it a condition for the production of chains of arguments as well as ... knowledge" (Hyldgaard, 2006, p. 150). With respect to teaching, this discourse has significant, potentially dangerous implications for students, due to the overt ideological force and unyielding authority conferred on the (master) signifier "teacher." Clearly, it is essential, though, to distinguish the emblematic teacher-as-signifier in Lacanian theory from actual flesh-and-blood teachers. In the Lacanian Master Discourse, the teacher has the capacity to decree truth ex cathedra, since this is the function of the master signifier; surely this is an exaggeration of the lived experience of real classrooms. Yet, according to Lacanian theory, it is not an exaggeration to presume that teachers valorize certain ethics and epistemes, which become incredibly persuasive to students, since the discursive arrangement in the classroom is built on the teacher's symbolic status as a master signifier.

While the Master Discourse represents the university at an institutional level, the University Discourse reflects the university prima facie. In some regards, the University Discourse is an emendation of the Master Discourse, intended to ensure the political legitimation of the University by making "systematic knowledge" the most powerful source of authority (Fink, 1995, p. 132). The pragmatic implication of these shifts is not to alter the configurations of knowledge, learning or

\footnotetext{
${ }^{4}$ In Lacanian terms, this is understood as alienation - the process of differentiation between the self and the world, which can only transpire via signification (symbolization, loosely).

5 The Lacanian "signifier" is an elusive, opaque concept. For our purposes, it can be understood as a singular, irreducible concept. The signifier, opposed to the signified, is the mental representation of a thing.

${ }^{6}$ Observant readers will note that this authority, while unilaterally declared, must be bilaterally conferred by the acceptance of the subject. The master remains master insofar as the subject accepts it as such.
} 
subjectivity, but rather to obscure the authoritative role of the Master Signifier. As Bruce Fink indicates,

the kind of knowledge involved in the university discourse amounts to mere rationalization, in the most pejorative Freudian sense of the term. We can imagine it, not as the kind of thought that tries to come to grips with the real, to maintain the difficulties posed by apparent logical and/or physical contradictions, but rather as a kind of encyclopedic endeavor to exhaust a field ...working in the service of the master signifier, more or less any kind of argument will do, as long as it takes on the guise of reason and rationality. (1995, p. 132-133)

Obviously, the University Discourse is untenable for teachers devoted to critical thinking. Rather than enabling students an opportunity to pursue genuine awareness or critical reflection, the University discourse conditions "knowledge," using its authority to negate opposition."

The Hysteric's Discourse basically inverts the University's Discourse, and represents the critical and reflective approach to teaching and learning. Herein, the subject (as opposed to the master signifier, or "knowledge") occupies the speaker's position, while "the real" occupies the position of truth. $^{8}$ The teacher, as "hysteric" or subject, takes an interrogative stance towards authority (as represented by the master signifier). Thus, rather than deferring to an arbitrary authority, "the real" is allowed to push through, overcoming the paradoxes and incoherencies. The "hysteric" is driven by a pursuit of the real. ${ }^{9}$ In non-Lacanian terms, the teacher, in pursuit of the truth ("reality"), questions and challenges the presuppositions of authoritative "knowledge." This represents an epistemology of constant, critical questioning. For Lacan, moreover, "the real" is fundamentally an element of the subject himself. Extending, and slightly modifying, this knowledge to suit our own educational considerations, then, we may see truth (the truth pursued through critical practice) as being accessible through a process of interrogative questioning (both extrinsic and intrinsic). For the critical approach, the truth is a deeply personal matter and can only come, ultimately from introspection and extrospection. Yet, the process of questioning, in Lacan's scheme, all too often adapts to the pressures of authority-that is, the Discourse of the Hysteric morphs, in time, into the Discourse of the University, and even into the Discourse of the Master. This can be seen in instances in which "critical thinking" becomes a purely rhetorical position, written into curricular codes and teaching manifestos, but not meaningfully followed in the classroom. It highlights the differentiation, as I will later explore, between "uncritical critical thinking" and "critical critical thinking" (Kincheloe, 2000). Additionally, as Blythe Clinchy writes, in a critical and reflexive piece, "When our students fail to meet the standards and become critical thinkers, the fault may not lie so much in them or me but in our standards. It is not that they are bad students or that I am a bad teacher, but that there is something deeply wrong about our enterprises" (1994, p. 32).

For Kincheloe, and Clinchy alike (as will be explored later in this piece), the institutional educational setting often fails to provide adequate support for critical thinking and critical instruction (systemic flaws in the "enterprise" of teaching). In Lacanian terms, this reveals an andragogical or pedagogical slip into the Discourse of the University and the Discourse of the Master. The objective

7 As archetypical, neither the Master Discourse nor the University Discourse should be taken as literal representations of university operations. Instead, these discursive paradigms hyperbolically represent the epistemological tensions relevant to teaching and learning in the realm of critical thinking.

${ }^{8}$ In Lacan's work, these positions are represented schematically, in "mathemes" (diagrams), which I exclude for the sake of concision and clarity. Within the mathemes, "the real" is referred to according to the unique Lacanian term objet $a$.

${ }^{9}$ Here, Lacan defies the traditional negative connotations associated with "the hysteric," depicting a symbolic figure who, in defiance of the deceptive rhetoric of rationality, pursues the ineffable truth of "the real." 
for critical educators is to remain in the Discourse of the Hysteric, always questioning, always challenging established epistemologies, and always drawing students into the critical debate. ${ }^{10}$

\section{Discourses of Self-Authorship: Teaching and Learning}

Implemented consistently and effectively, the criticality of the Discourse of the Hysteric serves to undermine the basic authoritarian schema (as found in the Discourse of the Master and, veiled, in the Discourse of the University) of much institutional educational epistemology. It unfixes "knowledge," making epistemology a condition of critical reflection, constantly in flux, and responsive to critical inquiry rather than epistemic authority structures. Yet, to what end? Faith in critical dynamism depends on a philosophical ethic. To assert, with conviction, that students ought to be encouraged and facilitated in thinking critically requires a belief that this kind of cognitive engagement is of benefit to them, and to the world around them. In particular, if we acknowledge that this kind of thinking can be-and indeed often is-discomforting, disillusioning and even a cause for crisis or trauma, we can only defend our androgogical means through a reasonable appeal to a desirable and viable end.

Examining the process of teaching critically through the Discourse of the Hysteric, we must note the principal objectives and functions of contemporary schooling; in addition to imparting facts and expertise, education facilitates a process of personal becoming. Fundamentally, education conditions the ways in which we subjectively learn to "be" in the world. Appealing to the existential concept of personal self-invention or creation, a burgeoning literature on "self-authorship" highlights this process of quasi-autopoiesis (the self's creation of a personal, enduring, subjective identity in the world) as a basic element of contemporary learning (Baxter Magolda, 2004). Fundamentally, "self-authorship" is a practice of self-reflective intellectual development, and since it is "a developmental goal fundamental to successful adaptation in the world of the twenty-first century," self-authorship is an essential consideration for educators (Wildman, 2007, pp. 15, 20). As Wildman explains,

cast in educational terms, the basic premise [of self-authorship] is that schools serve not only to keep and convey knowledge, but also to provide those special assistive conditions that can nudge minds to life. This assertion of new roles for schools is a natural progression of the growing body of research showing how education can shape development, but also how epistemological development is essential for effective learning. (2007, p. 15)

Educators, according to this theoretical perspective, operate as learning facilitators (rather than strictly professorial authorities), catalyzing a process of epistemological development through thoughtful reflection and questioning. Instead of casting aside the traditional perspective on education as fact and expertise impartation, self-authorship proponents strive to integrate this function with the value of critical questioning and subjective self-definition (Wildman, 2007; Baxter Magolda, 2007; Meszaros, 2007). Contextually, this is of exigent contemporary importance, Peggy Meszaros writes, because "expectations of higher education in the twenty-first century include overarching goals of effective citizenship and outcomes such as critical thinking, mature decision making, appreciation of multiple perspectives and difference, and interdependent relationships with others" (2007, p. 5; see also Baxter Magolda, 2004).

${ }^{10}$ Although certain pedagogues, Mark Bracher in particular (throughout his work), have argued on behalf of implementing the Discourse of the Analyst as a pedagogical technique, I have disputed this claim elsewhere. While the Discourse of the Analyst presents an ideally attractive schema for teaching (since it seeks to emphasize and access students immanent "identity contents"), it is untenable on pragmatic and ethical grounds (since it was intended as a means of psychotherapeutic treatment, trying to transpose it into the classroom presents irresolvable logistic and moral dilemmas). 
Critical self-authorship is, by all accounts, a difficult and at times insecure process. Focusing on an andragogy of critical reflection and self-authorship, we must acknowledge that structures of epistemological authority often work against our reflective goals. For "many students," Marcia Baxter Magolda writes,

Extracting themselves from what they have uncritically assimilated from authorities to define their own purposes, values, feelings, and meanings involves far more than information and skill acquisition. It requires a transformation of their views of knowledge, their identity, and their relations with others. Twenty-first-century learning outcomes require self-authorship: the internal capacity to define one's belief system, identity, and relationships. (2007, p. 69)

The rubrics of self-authorship discourse fit optimally within a teaching practice adherent to the Discourse of the Hysteric. By reconstituting knowledge and learning as practices of self qua selfauthorship, a space is created for critical thought. Self-authorship finds locus in an episteme where knowledge-authority is problematized; "knowledge," herein, can be validated only by critical reflection, and to be (or become) meaningful it must be integrated effectively into the process of self-authorship.

\section{Critical Thinking}

To adhere to the Discourse of the Hysteric and remain philosophically consistent, we must critically and analytically scrutinize the concept of "critical thinking" itself; it would, ultimately, be both ironic and self-defeating to treat this term as self-evident. What is intended by all the enthusiastic injunctions to critical thought? More importantly, what do they mean? Surely, there are innumerable, nuanced conceptions to which the term pertains, ranging from general thoughtfulness to extensively deliberative critique.

For influential theorist Henry Giroux, critical thinking in the educational setting involves students' learning

how to be able to move outside of their own frame of reference so that they can question the legitimacy of a given fact, concept, or issue ... [and learning] how to perceive the very essence of what they are examining by placing it within a system of relationships that give it meaning. In other words, students must be taught to think dialectically. (1994,p. 202)

Laura Kaplan extends this conceptualization by giving it a purposive import-students must learn to think critically so as to realize their own cognitive independence and "intellectual autonomy" (1994, pp. 205-219). As Lenore Langsdorf notes, critical thinking must be conceived as processual and purposive, functioning as both a "technique" and a "means for enlightenment" 1994, p. 233). Clinchy (1994) emphasizes a crucially important point, relevant to critical thinking: it is not an abstract exercise, but a process of tremendous subjective relevance and personal import to the thinker or knower. Critical thinking is not a mental exercise, but requires "connected knowing," a form of knowledge that entails a meaningful sentimental and intellectual attachment to what is known or considered (Clinchy, 1994, pp. 38, 39). Drawing on these insights, for our purposes, "critical thinking" must be understood as an honest, courageous, cognitive practice. To "think critically" requires a bold evaluation of all available information. It is the criticism and assessment of facts and perspectives, acknowledging and critiquing even the most discomfiting and seemingly distorted views. Critical thinking exists somewhere between thesis and antithesis, synthesizing the polarities according to a thorough, intentional and reasonable adjudicative standard. Without a doubt, critical thinking is an uneasy enterprise, and to maintain integrity, critical thinkers must be willing to accept outcomes to which they are sentimentally opposed. 
At its root, critical thinking is a deeply personal process, in which the self-as-subject negotiates subjectivity through courageous examination of "the self" and "the other."

As Langsdorf emphasizes, critical thinking may be measured, to some extent, according to its results (1994). If one pontificates in a critical fashion, one will invariably be affronted with difficult and trying truths. One discovers oneself to be, varyingly, ignorant, egoistic, partial, prejudiced, and complicit in tremendous injustice. These are difficult revelations. Critical thinking, accordingly, is precursory to challenge and change, or to a pressure for change. One's critical reflections mandate personal struggles for change; accordingly, critical thinking is a radical procedure, disavowing the untenable realities of the present, and progressing towards an ameliorated future. As such, critical thinking typifies the Discourse of the Hysteric. The critical figure, represented by the Hysteric, interrogates his material, social and political conditions by evaluating the knowledge with which he is presented (and within which he is situated). The natural outcome of this process is discomfort, agitation - intra-cognitive agitation, and socio-political agitation for change.

It is not enough, Kincheloe emphasizes, to pay lip-service to critical thinking while merely enforcing a conservative epistemology. We must differentiate between "uncritical critical thinking" and "critical critical thinking;" since authentically

critical thinking moves in an emancipatory direction with an omnipresent sense of selfawareness. Moving in an emancipatory direction implies a concern with the development of a liberated mind, a critical consciousness.... Teachers as critical thinkers are aware of the construction of their own consciousness and the ways that social and institutional forces work to undermine their autonomy as professionals. Emancipatory teacher thinking sets the self 'in question.' (Kincheloe, 2000, p. 27).

The emancipatory ethic that underlies this critical discourse returns our focus to the institutional considerations of higher education. There is an unmistakable rhetorical attachment to "critical thinking" across university spectra, particularly in the liberal arts and humanities. Lacan's theory of the University Discourse, however, avers that this professed adherence never (within the institutionalized discourse) meaningfully transcends the rhetorical level. It is essentially "uncritical critical thinking," that establishes "critical thinking" as a master signifier-a symbolic authority that itself remains unchallenged and galvanizes the authority structure by its own status. More precisely, the University Discourse elevates "critical thought" as "knowledge" to an authoritarian significance. Hereby "critical thinking" is co-opted into a hegemonic epistemology, institutionalized as a rhetorically valid, but fundamentally illusory, value (Horn, 2000: 141). Simply put, the institutionalization of so-called "critical thought" serves to politically legitimate the University Discourse, by presenting it as dynamic and open to criticism; however, this rhetorical valorization undermines and subverts true critical process by delineating and limiting the very definition and conditions of "knowledge" itself. ${ }^{11}$ Boler insightfully situates this epistemological subversion in a broader socio-political context; "the call for 'critical inquiry' in the liberal tradition," she writes,

is easily subsumed within the hollow invocations of values of dialogue, democracy, and rationality. Deeply rooted in Western conceptions of liberal individualism, this common

\footnotetext{
${ }^{11}$ It is necessary to highlight the distinction between Lacan's paradigmatic theory of the University Discourse, and the reality of discourse within actual universities. If educational discourse conformed exclusively to the University Discourse, criticality would be fundamentally impossible, rendering reflective reformism moot. In actuality, discourse within universities possesses traits of all four Lacanian discourses, creating the possibility for critical, emancipatory, and anti-oppressive education. This paper contends that the hegemonic, institutional epistemological structures of Western post secondary institutions tend towards the University Discourse paradigm, but that critical andragogy offers a possibility for resistant discourses.
} 
rhetoric threatens to reduce genuine inquiry to an individualized process with no collective accountability. (1999, p. 177)

These illusory, rhetorical pretenses of critical thinking fundamentally disagree with the profound processes of critical engagement articulated by the above-cited scholars. Vis-à-vis these institutional and socio-epistemic restraints (and their contradiction with the accepted meanings of critical thinking, within critical education scholarship), we are confronted with an urgent question: how can critical thinking be retrieved from the neutralization it faces in the context of institutionalized epistemological authority?

\section{Reflective Practice}

Reflexivity-understood as the dynamic thought process underlying reflective practice-provides a means by which to assess and validate our critical thinking methodology. By consistently turning the reflexive gaze inwards, and engaging in a synchronous, contextual critique of ourselves and the world around us (including the "knowledges" conferred on us in educational settings, and the epistemological pressures we face as teachers and students), we can continually refresh our critical thinking practices. As Donald Schön has emphasized in a number of pivotal works, this dialectical critical process is a central component of reflective practice $(1983,1987)$. The so-called "reflective practitioner" is a thoughtful, critiquing subject, who ceaselessly questions personal knowledge structures, and strives to understand how they are situated in relation to the social institutions and practices in which he participates. It is precisely this awareness that critical educators seek to encourage in their students. This introspective and extrospective process of questioning and critique both utilizes and secures critical thinking by employing it methodically, and protecting it from formalistic reduction and degradation. Accordingly, educators can encourage critical and reflective thinking; however, this type of thought process is a uniquely individual, subjective engagement. Institutions are not necessarily critical or reflexive, but the individuals within them can be. Similarly, the Discourse of the Hysteric is not in itself a reflective practice, but rather constitutes a framework for the critically reflective and interrogative practices of a subjective speaker, the teacher, who enacts it.

In an exemplary paper on reflexivity, Davies et al. turn a poststructuralist, critical gaze towards self-reflexive subjectivity. As Lather has written on self-reflexivity, "there are few guidelines for how one goes about the doing of it, especially in a way that is both reflexive and, yet, notes the limits of selfreflexivity" (1993, quoted in Davies et al., 2004, pp. 361-362). To wit, self-reflexivity must not be taken as a non-contextual or unassailably "true" epistemological technique. It is, according to the finitude of personal perspective, a limited entity. Moreover, it is ad hoc, responding to specific demands and considerations; the self-reflexive self is invariably situated within his own perspective, without a complete or objective purview. Further complicating the issue, self-reflexivity is subject to itself. In a potentially ceaseless layering process, critical reflexivity can be turned inwards, evaluating itself and its epistemological conditions, ad infinitum. In need of pragmatic concretion, we may ground our reflexive technique in a provisional definition; reflexivity

entails the development of a kind of 'critical literacy' in which the researchers understand that they are also caught up in the processes of subjectification and see simultaneously the objects/ subjects of their gaze and the means by which those objects/subjects (which may include the researcher as subject) are being constituted. (Davies et al., 2004, p. 361)

Under the lens of self-scrutiny, reflexive practice reveals its own limitations. It cannot be treated as infallible, or unequivocal. In fact, central to reflective practice is the fundamental tenet of equivocation. 
One of the primary insights to be garnered by reflective introspection is a knowledge of the inevitable partiality and subjective limitation of one's own critical faculties.

The Discourse of the Hysteric readily integrates the fallibility and imperfection of reflective practice. Rather than absolute, authoritative knowledge, the process of questioning, as ding an sich, is preeminently important. "The real" which is sought and attained through this questioning is, necessarily and self-consciously, a partial, subjective real, pertinent to the inquiring subject's own self. This is not a reality in which the subject may be securely grounded and unflinchingly certain. Rather, it is precisely the real of the subject's uncertainty, the real that consists of the process of unending critical questioning itself. Paradoxically, the reflexively questioning subject is grounded only in the interminable process of critical questioning. No absolute answers obtain (indeed, absoluteness is only plausible for the Discourse of the Master and the Discourse of the University, and hangs entirely on the foundation of a singular, arbitrary nodal point or signifier).

Pragmatically, however, we must militate against the insecurity engendered by (this interpretation of) the Discourse of the Hysteric. To define critical inquiry only in relation to uncertainty and unending questioning is to risk the reduction of "truth" to an exclusively personal matter, or-worse yet - to fundamental elusion. The solipsism, or even nihilism, implied by this reduction, is untenable in a teaching practice that endeavours to help students, and ameliorate oppressive or unjust social conditions. Clinchy's conception of "connected knowing," provides a way to resolve the need for a balance between (apparently) immanent truths and external sources of knowledge. In Clinchy's conceptualization, "connected knowing" entails an integration of intellectation and sentiment-a synchronicity between the emotional and the intellectual. Connected knowing involves meaningful empathy for another person, or another perspective. Connected knowers, "try to get inside [others' knowledge] and form an intimate attachment," Clinchy writes;

The heart of connected knowing is an imaginative attachment: trying to get behind the other person's eyes and 'look at it from that person's point of view'... You must suspend your belief, put your own views aside, try to see the logic in the idea. You need not ultimately agree with it...You must empathize with it, feel with it and think with the person who created it. Emotion is not outlawed ...but reason is also present. (1994: 39)

In light of the emancipatory and anti-oppressive objectives of critical pedagogy, Clinchy's "connected knowing" is an ideal way to reconcile foundational ethical commitments-to justice, intellectual and social emancipation, and critical inquiry -with the uncertainty of critical, reflective practice (which yields the knowledge that there is always "work to be done," in these respects).

Reflective practice is not an end game. It originates in the conviction that it will always be necessary, that it can never be fully "completed." Seen in this light, critical thinking is a process of striving, of immanent working towards avowed objectives-like enlightenment, justice and emancipation. It is in this regard that critical, reflective teaching, within the Discourse of the Hysteric, is an endless task, a work that can never be complete. The dialectic between teacher and student is marked by bilateral critical engagement and reflexivity. In drawing the student towards genuine critical ideation, the teacher must be a true "reflective practitioner" (a "critical critical thinker"). By contrast, the teacher who merely extols the rhetoric of critical thought, without meaningfully enacting it, is just an ambassador of institutional epistemological authority, caught in the Discourse of the Master or the Discourse of the University. Thus, as Funmi Amobi writes, we must "pay more attention to our own voices about reflection, how we do it and how we engage our students in it. Problematizing our teaching in this way...should help us to advance the cause of teacher reflection in which we are mutually engaged” (2005, p. 317).

Learning to "think critically" is coextensive with learning to accommodate certain forms of fundamental uncertainty. Dwelling within this incertitude, the reflective questioner constantly seeks the unattainable (complete justice, freedom, equity, and enlightenment). This impossible pursuit is 
inextricable from the psychological trauma that is invariably yielded by one's devotion to "critical thinking" (and the awareness that the desired objectives will never be fully attained). Consequently, to the extent that post secondary liberal arts andragogy implements the Discourse of the Hysteric by fostering actual critical thinking, it forfeits any claim to being harmless and is-from a perspective that equates harm with trauma, insecurity and negative affect—clearly harmful.

\section{Primum non Nocere-An Undesirable Ideal}

According to a particular understanding of harm, the valorization of critical thinking and the attempt to teach it functionally harm students. This is certainly not a free license for ill-intentioned teachers to sadistically damage their students. Admittedly, any teaching philosophy that permits harming students as a legitimate educational objective must be very meticulous in defining its terms and goals. Subjective trauma or harm, in the Lacanian sense, must not be conflated with unease, difficulty, or mere disillusionment (although it generally entails elements of these). How, then, does this andragogical epistemology, rooted in the Discourse of the Hysteric, define "harm"?

First, the kind of pedagogical harm legitimated in this schema is equated to a specific kind of psychological trauma. It presupposes that "thinking critically" and reflectively reveals certain truths that are, generally, damaging to a student's ego and self-assuredness. Seeing these truths-which can facilitate radical discourses of social change and emancipatory citizenship-forces us to recognize the endemic injustice and cruelty in the world around us. Moreover, and more disconcertingly, this involves an accession of "the (Lacanian) real" in which students are called upon to reflexively examine, and critically explore their own complicity. Recognizing oneself to be prejudiced (racist, sexist, phobic of sexual difference, and xenophobic towards difference in general) must be acknowledged as harmful to one's self-image. Similarly, recognizing oneself as a facilitating agent (through, for example, contemporary consumerist participation) of social injustice can be harmful to one's self-image. In essence, critical thinking is injurious to the myths of social nicety so often perpetuated in early stages of education and socialization. To the extent that these myths have been integrated into a student's ego or subjectivity, losing them is traumatic or harmful.

As Ann C. Berlak writes, anti-oppressive pedagogy or andragogy involves "trauma, erasure, mourning, and expression of feeling in classrooms" (2004, p. 123). Anti-oppressive pedagogical moments, she asserts, involve significant ruptures and traumas, which produce a need for reconciliation and reckoning, which can prove profoundly productive with respect to personal growth. Writing specifically on racial tensions, Berlak asserts that "what enabled students to begin to witness racism," in her classroom, was the "speaker's expression of anger in response to racism, which in turn aroused in students feelings that had previously been unrecognized, unspeakable and unspoken" (p. 123). For Berlak, in agreement with the Discourse of the Hysteric, "a major purpose of teaching is to unsettle taken for granted views and feelings," and, consequently, "confrontation, with its attendant trauma, and reflection upon the trauma are necessary" (pp. 123-124). This keen vision of important classroom ruptures can be extended to most, perhaps all, forms of prejudice. Additionally, Berlak provides an invaluable insight into the nature of pedagogical trauma, which, in her esteem, "refers both to massive, painful, isolated events outside the normal range of human experience and to daily insidious and persistent events that continue to re-injure" (p. 134). ${ }^{12}$ Especially in the context of self-recognition (coming to see oneself, honestly, in a light that is subjectively damaging), singular reflective events

\footnotetext{
${ }^{12}$ For Berlak, who draws on the work of Shoshana Felman, trauma is associated with witnessing (becoming aware of the trauma, rather than simply denying it). I agree fundamentally with this dual vision of trauma-andwitnessing, and while the concept of witnessing is not explored in this piece, it has been brilliantly dealt with by Berlak, (2004) and Felman and Laub (1992).
} 
"outside the range of normal experience" constitute the first form of critically reflective trauma I advocate.

Second, "critical thinking" is enduringly harmful in Berlak's sense of "persistent events that continue to re-injure". I argue that critical thinking itself is unendingly harmful to one's sense of subjectivity (which, in the psychoanalytic tradition, entails ongoing denial, repression, and justification). This cannot be seen as an ephemeral trauma, to be overcome by a moderate degree of subjective adjustment. To truly think critically yields a fundamentally unfixed epistemology; it rests in the paradoxical certainty of uncertainty (comparable to the classic tenet that "change is the only constant"). Critical thinking opposes epistemic absolutism; "truth" is understood to be circumstantial, perspectival, and contingent (Davies et. al., 2004). ${ }^{13}$ Critical thinking perpetually debunks absolutism, and cognitiveexistential and philosophical uncertainties ensue. Relative to the secure, epistemologically constant subjectivity inculcated and reinforced in early education, this realm of uncertain "knowing" is a traumatized, de-centered subjectivity. ${ }^{14}$ The Discourse of the Hysteric, in generating critical and reflective discourse in students, is the pedagogical equivalent of kicking students' feet out from beneath them.

Confoundingly, the notion of harm logically requires a conceptually extant "healthy" or "unharmed" state of being. Like "harm," however, the Discourse of the University and the institutional writs of specific universities presuppose the self-evidence and inherent legitimacy of "health". Generally, subjective "health" is treated as tantamount to "normal" social functioning. Indeed, it is evident that these terminologies devolve immediately into hopeless tautology. For all intents and purposes, subjective "health" is viewed as inextricable from positive affect. Mental "health" is a defined according to one's ability to "function properly" and attain positive affect. Critical examination reveals the precariousness of these designations. The semantics of "health" and "harm" are in themselves contextual, socially and temporally specific, and open to debate and disputation. A legitimate counterargument against a pedagogy of harm might assert that it is justificable to inflict discomfort for andragogical purposes, but that it is unacceptable to inflict (or promote the infliction of) harm — as "harm" connotes a severe form of damage; yet, this a basically semantic objection. By "harm," I envision simply a Lacanian form of subjective harm, in which the subject's sense of self is damaged. This harm should be neither fundamentally crippling, nor irremediable. In fact, the very purpose of this harm or trauma is to compel one to reconcile oneself through a process of selfreinvention or personal growth. Thus, within the Discourse of the Hysteric, we may readily engage in a critical poststructuralist critique of the language involved, uncovering the fact that "health" and "harm" function as master signifiers, covering over their own arbitrariness by a heavy-handed assertion of tautological authority. Only within the lexicon of University/Master Discourse can the trauma of critical thinking be deemed "harmful." Seen otherwise, without the value-loaded suppositions that inhere within the University epistemology, the cognitive trauma and discomfort of epistemic uncertainty are simply the inevitable outcomes of critical thinking and reflective practice.

Even within the University's ethical postulates and semantics of harm, however, there are abundant incoherencies. For those who might be reluctant to engage in an intentionally "harmful" andragogy, it must be noted that many university practices are inevitably and unapologetically harmful.

\footnotetext{
${ }^{13}$ Certainly, I do not intend to abnegate the eternal ontological question of "Truth," questioned as a philosophical absolute. Rather, my position is that critical thinking addresses the uncertainty and specificity of personal "truth"- reality as it is subjectively perceived and filtered.

${ }^{14}$ This essential uncertainty does not preclude the existence of social, political and molecular "facts" present in the world. In fact, the trauma of "realization" (the aforementioned realization of injustice in the world, for instance) requires a subjective acknowledgment of these facts. Rather, I am arguing that through critical thinking, one experiences the stark, fundamental trauma of uncertainty - uncertainty in formulating a relationship with these "facts" and with respect to the very conditions of perception and mental integration through which these facts are "known".
} 
As Clive Harber explicates, schooling is multifariously violent act. Taken on the level of cultural relativism, the Western school tradition has been rampantly and intentionally violent towards divergent cultures-under colonialism, for instance, and with respect to the sanctions imposed on culturally divergent ways of "knowing" (Harber, 2004, pp. 4-18, 85-96). On an individual level, schools mete out violent harm as a matter of course. The fundamental structures of performance measurement, and educational assessment provoke such stress, Harber reveals, in that they cause psychological and even physical harm. This harm transpires largely through

a competitive assessment and selection mechanism with 'winners' and 'losers' at all levels. While competition does not necessarily lead to violence against [students] in a linear fashion, the avoidable consequence of this is the over-emphasis on testing and examinations, which is causing unacceptable levels of physical harm to pupils. (Harber, 2004, p. 112)

Looked at critically, formal education reveals itself to be fundamentally and structurally harmful. It is my position that the harm evoked by facilitating critical thinking is more desirable and conscionable than the rigid, authoritarian impositions of standardized assessment (which remain unquestioned by the Discourse of the University). Ultimately, in valorizing critical thinking as a preeminent learning objective, I am presenting a simple educational schematic: learning through trauma, and trauma through learning.

\section{References}

Alanis, J. (2006). How much are you willing to risk? How far are you willing to go? Cultural StudiesCritical Methodologies, 6(1), 166-184.

Amobi, F. A. (2005). Turning the focus on ourselves; teacher education professors' reflectivity on their own teaching. Reflective Practice, 6(2), 311-318.

Baxter Magolda, M. B. (2004). Self-Authorship as the common goal of $21^{\text {st }}$ century education. In M. B. Baxter Magolda and P.M. King (Eds.), Learning partnerships: Theory and models of practice to educate for self-authorship. Sterling, VA: Stylus.

Baxter Magolda, M. B. (2007). Self-authorship: The foundation for twenty-first-century education. New Directions for Teaching and Learning, 109, 69-83.

Baxter Magolda, M. B., \& King, P.M. (Eds.). (2004). Learning partnerships: Theory and models of practice to educate for self-authorship. Sterling, VA: Stylus.

Berlak, A. C. (2004). Confrontation and pedagogy: Cultural secrets, trauma, and emotion in antioppressive pedagogies. In M Boler (Ed.), Democratic dialogue in education: Troubling speech, disturbing silence (pp.123-144). New York: Peter Lang.

Boler, M. (1999). Feeling power: Emotions and education. Florence, KY: Routledge.

Bracher, M. (1999). Transference, desire, and the ethics of literary pedagogy. College Literature, 26(3), 127-146.

Clinchy, B. M.. (1994). On critical thinking and connected knowing. In Walter, K. S. (Ed.), Re-thinking reason: New perspectives in critical thinking (pp. 33-42). Albany, NY: State University of New York Press.

Davies, B., Browne, J., Gannon, S., Honan, E., Laws, C., Mueller-Rockstroh, B., et al. (2004). The ambivalent practices of reflexivity. Qualitative Inquiry, 10(3), 360-389.

Durkheim, E. (1932/1956). Education and sociology. New York: Free Press.

Felman, S. \& Laub, D. (1992). Testimony: Crises of witnessing in literature and psychoanalysis. New York: Routledge.

Fink, B. (1995). The Lacanian subject: Between language and jouissance. Princeton, NJ: Princeton University Press. 
Foucault, M. (1980). Power/knowledge: Selected interviews and other writings, 1972-1977 (C. Gordon, Trans.). Brighton, UK: Harvester Press.

Gehring, T. (2000). A compendium of material on the pedagogy/andragogy issue. Journal of Correctional Eduation, 51(1), 151-162.

Giroux, H. (1994). Toward a pedagogy of critical thinking. In W. Kerry (Ed.), Re-thinking reason: New perspectives in critical thinking. (pp. 199-204). Albany, NY: State University of New York Press.

Harber, C. (2004). Schooling as violence: How schools harm pupils and societies. New York: RoutledgeFalmer.

Hirst, P. H. \& White, P. (Eds.). (1998). Society and education. New York: Routledge.

Horn, R.A. Jr. (2000). Becoming a critical teacher. In D. Weil \& H. K. Anderson (Eds.), Perspectives in critical thinking: Essays by teachers in theory and practice (pp. 139-172). New York: Peter Lang Publishing Inc.

Hyldgaard, K. (2006). The discourse of education-The discourse of the slave. Educational Philosophy and Theory, 38(2), 145-158.

Kaplan, L. D. (1994). Teaching intellectual autonomy: The failure of the critical thinking movement. . In K. S. Walter. (Ed.), Re-thinking reason: New perspectives in critical thinking (205-220). Albany, NY: State University of New York Press.

Kincheloe, J. L. (2000). Making critical thinking critical. In D. Weil \& H. K. Anderson (Eds.), Perspectives in critical thinking: Essays by teachers in theory and practice (pp. 23-40). New York: Peter Lang Publishing Inc.

Kumashiro, K. (2002). Troubling education: Queer activism and anti-oppressive pedagogy. New York: RoutledgeFalmer.

Lacan, J. (1988). The seminar of Jacques Lacan, book XX: On feminine sexuality, the limits of love and knowledge, 1972-1973 (B. Fink, Trans.). New York: W.W. Norton \& Company Ltd.

Langsdorf, L. Is critical thinking a technique, or a means of enlightenment? In K. S. Walter (Ed.), Rethinking reason: New perspectives in critical thinking (pp. 233-256). Albany, NY: State University of New York Press

Meszaros, P.S. (2007). The journey of self-authorship: Why is it necessary? New Directions for Teaching and Learning, 109, 5-14.

Parker, I. (2001). Lacan, psychology and the discourse of the university. Psychoanalytic Studies, 3(1), 6777.

Schön, D. A. (Ed.). (1991). The reflective turn: Case studies in and on educational practice. New York: Teachers College Press.

Schön, D. A. (1987). Educating the reflective practitioner. London: Jossey-Bass Publishers.

Schön, D.A. (1983). The reflective practitioner: How professionals think in action. New York: Basic Books.

Weil, D. (2000). Learning to reason dialectically: teaching primary students to reason within different points of view. In D. Weil \& H. K. Anderson (Eds.), Perspectives in critical thinking: Essays by teachers in theory and practice (pp. 1-22). New York: Peter Lang Publishing Inc.

Wildman, T. M. (2007). Taking seriously the intellectual growth of students: Accommodations for selfauthorship. New Directions for Teaching and Learning, 109, 15-30.

Zembylas, M. (2006). Witnessing in the classroom: The ethics and politics of affect. Educational Theory, 56(3), 305-324.

\section{About the Author}

Michael D. Berry is a Master of Education student in Theoretical, Cultural and International studies at the University of Alberta. He has a background in Sociology and philosophy of education, with focus on theory. His interests include: social and ethical philosophy, pedagogy, radical pedagogy, cultural studies and psychoanalysis. He can be contacted at mberry@ualberta.ca. 